\title{
UPRAVNOSUDSKA I USTAVNOSUDSKA KONTROLA ZAKONITOSTI AKATA JEDINICA LOKALNE I PODRUČNE (REGIONALNE) SAMOUPRAVE
}

Dr. sc. Marko Šikić, izvanredni profesor

Dr. sc. Mateja Crnković, viša asistentica

Pravni fakultet Sveučilišta u Zagrebu
UDK: 352.071

Ur.: 1. veljače 2016.

Pr.: 14. ožujka 2016.

Prethodno priopćenje

\begin{abstract}
Sažetak
Reforma upravnog sudovanja je kroz novu regulaciju upravnog sudovanja $i$ ustrojstva upravnih sudova izazvala promjene i u posebnom zakonodavstvu. Tako su nastupile izmjene Zakona o lokalnoj i područnoj (regionalnoj) samoupravi, a za ovaj je rad važna promjena u pogledu sudske kontrole nad aktima jedinica lokalne i područne (regionalne) samouprave koju su prije reforme obavljali Upravni sud Republike Hrvatske te Ustavni sud. Ustavni sud je prema trenutnom uređenju nadležnost za kontrolu ustavnosti $i$ zakonitosti zadržao samo nad statutima lokalnih jedinica. Za kontrolu općih akata koje donose lokalne jedinice nadležan je Visoki upravni sud Republike Hrvatske. U radu su analizirana i poredbena rješenja vezana uz problematiku sudske kontrole općih akata jedinica lokalne i područne (regionalne) samouprave, i to francusko, njemačko i slovensko uređenje.
\end{abstract}

Ključne riječi: sudska kontrola, opći akti jedinica lokalne i područne (regionalne) samouprave, upravna reforma.

\section{1. $U V O D$}

U posljednjih je nekoliko godina sudska kontrola nad aktima jedinica lokalne i područne (regionalne) samouprave prošla obuhvatne izmjene. Glavnina izmjena usko je vezana uz reformu upravnog sudovanja koja je rezultirala donošenjem i stupanjem na snagu Zakona o upravnim sporovima (dalje: ZUS) ${ }^{1}$. Jedna od važnijih posljedica recentnih promjena u upravnosudskoj strukturi jest i izmjena Zakona o lokalnoj i područnoj (regionalnoj) samoupravi (dalje: ZLRS) ${ }^{2}$ u dijelu koji se odnosi na nadzor nad aktima jedinica lokalne i područne (regionalne) samouprave. Unatoč

1 Zakon o upravnim sporovima, NN 20/10, 143/12, 152/14.

2 Zakon o lokalnoj i područnoj (regionalnoj) samoupravi, NN 33/01, 60/01, 129/05, 109/07, 125/08, 36/09, 36/09, 150/11, 144/12, 19/13. 
vidljivim promjenama koje su uglavnom pozitivno ocijenjene, ipak se u navedenim zakonskim rješenjima našlo i nedoumica koje opterećuju prvenstveno sudove pri odlučivanju o zakonitosti i ustavnosti navedenih akata, ali imaju i dalekosežne posljedice na ostvarivanje zaštite subjektivnih prava građana te objektivnog pravnog poretka.

\section{SUDSKA KONTROLA AKATA JEDINICA LOKALNE I PODRUČNE (REGIONALNE) SAMOUPRAVE}

Nakon reforme upravnog sudovanja i u okviru CARDS-a, odnosno twinnig projekta „Podrška razvoju učinkovitijeg i modernijeg funkcioniranja Upravnog suda Republike Hrvatske, donesen je ZUS. Njime je propisano da u prvom stupnju odlučuju upravni sudovi, a u drugom Visoki upravni sud Republike Hrvatske (dalje: VUS). Upravni sudovi nadležni su za odlučivanje o tužbama protiv pojedinačnih odluka javnopravnih tijela, o tužbama protiv postupanja javnopravnih tijela, o tužbama zbog propuštanja donošenja pojedinačne odluke ili postupanja javnopravnog tijela u zakonom propisanom roku, o tužbama protiv upravnih ugovora i izvršavanja upravnih ugovora te u drugim zakonom propisanim slučajevima. ${ }^{4,5}$

Upravni sudovi smješteni su u četiri najveća grada Republike Hrvatske, pa tako postoje Upravni sud u Zagrebu, Upravni sud u Rijeci, Upravni sud u Osijeku i Upravni sud u Splitu. Područja koja pokrivaju određena su Zakonom o područjima i sjedištima sudova. ${ }^{6}$

VUS je smješten u Zagrebu, a njemu je u nadležnost sukladno članku 3. stavku 2. ZUS-a stavljena ocjena zakonitosti općih akata tijela jedinica lokalne i područne (regionalne) samouprave, pravnih osoba s javnim ovlastima i pravnih osoba koje obavljaju javnu službu. Osim ove nadležnosti, VUS odlučuje o žalbama protiv presuda upravnih sudova i rješenja upravnih sudova protiv kojih je dopuštena žalba, o sukobu nadležnosti između upravnih sudova te u drugim zakonom propisanim slučajevima (čl. 12. st. 3. ZUS-a). ${ }^{7}$

3 O CARDS programu v.: http://eur-lex.europa.eu/legal-content/EN/TXT/HTML/?uri=URISE RV:r18002\&from $=$ EN

4 Čl. 12. st. 2. ZUS-a i čl. 22. Zakona o sudovima, NN 28/13, 33/15, 82/15.

5 Šire o predmetu, nadležnosti i ostalim institutima novog upravnog spora v. u: Đerđa, Dario, Šikić, Marko, Komentar Zakona o upravnim sporovima uz uvodni članak Dragana Medvedovića Novi sustav upravnog sudovanja, Novi informator, Zagreb, 2012.

6 Zakon o područjima i sjedištima sudova, NN 128/14. Tako je za područja Koprivničkokriževačke, Krapinsko-zagorske, Međimurske, Varaždinske, Sisačko-moslavačke, Bjelovarsko-bilogorske, Zagrebačke županije i Grada Zagreba nadležan Upravni sud u Zagrebu. Za područja Dubrovačko-neretvanske, Šibensko-kninske, Splitsko-dalmatinske i Zadarske županije nadležan je Upravni sud u Splitu. Upravni sud u Rijeci nadležan je za područja Istarske, Primorsko-goranske, Ličko-senjske i Karlovačke županije, a u Upravni sud u Osijeku za područja Brodsko-posavske, Osječko-baranjske, Požeško-slavonske, Virovitičko-podravske i Vukovarsko-srijemske županije (čl. 9. Zakona o područjima i sjedištima sudova).

7 V. i čl. 25. Zakona o sudovima. 
Budući da se reforma upravnog sudovanja odnosila i na kontrolu općih i pojedinačnih akata reguliranih u ZLRS-u, krajem 2012. izmijenjen je i dopunjen ZLRS. ${ }^{8}$ U članku 133. Ustava Republike Hrvatske9 (dalje: Ustav) građanima je zajamčeno pravo na lokalnu i područnu (regionalnu) samoupravu. Lokalna samouprava podrazumijeva pravo i mogućnost građana da uređuju i upravljaju bitnim dijelom javnih poslova u okvirima koji su im određeni zakonom, uz vlastitu odgovornost i u interesu lokalnog pučanstva. ${ }^{10}$ Prema ZLRS-u, akti koje donose jedinice lokalne i područne (regionalne) samouprave dijele se na opće i pojedinačne. Iako je ZLRS-om jasno propisano koji su to opći, a koji pojedinačni akti, regulacija kontrole nad njima nije potpuno precizna i nedvosmislena, a uz to je potrebno imati na umu da se razlikovanje općih ${ }^{11}$ i pojedinačnih akata provodi s obzirom na materiju, odnosno sadržaj što nužno vodi različitim tijelima koja kontroliraju njihovu zakonitost. Opći akt je generalno i apstraktno pravno pravilo koje vrijedi za neodređen broj slučajeva. ${ }^{12}$ Upravni akt se, s druge strane, odnosi na konkretan ${ }^{13}$ slučaj. ${ }^{14}$ Njime se zasniva pravni, tj. upravnopravni odnos. ${ }^{15}$ To pojmovno razlikovanje isključuje mogućnost općeg akta za pojedini slučaj. ${ }^{16}$ Upravnom i općem aktu zajednička je upravna vlast koja je donositelj obaju akata. Opći akt se podudara sa zakonom u svojoj apstraktnosti, a s upravnim aktom u tome što je donositelj beziznimno upravna vlast koja je općim aktom i sama vezana. Iako opći akt i upravni akt donosi upravna vlast, unutar nje u pravilu ih donose hijerarhijski različita upravna tijela. Daljnja razlika je u propisima koji predviđaju njihovo donošenje, a sve to utječe na način provedbe kontrole zakonitosti upravnog i općeg akta. ${ }^{17}$

8 Više o izmjenama ZLRS-a u dijelu koji se odnosi na odnose centralne države i lokalne samouprave v. u Crnković, Mateja, Novine u odnosu centralne države i lokalne samouprave koliko i kakvog nadzora, Dvadeset godina lokalne samouprave u Hrvatskoj, u: Koprić, Ivan, Đulabić, Vedran (ur.), Institut za javnu upravu, Zagreb, 2013., str. 223-253.

9 Ustav Republike Hrvatske, NN 56/90, 135/97, 113/00, 28/01, 76/10, 5/14.

10 Koncepcija lokalne samouprave prema čl. 3. st. 1. Europske povelje o lokalnoj samoupravi, NN-MU 14/97, 4/08.

11 Krbek u svom djelu Sudska kontrola naredbe iz 1939. analizira naredbu (uredbu). Ovdje je uzeta za primjer, jer, iako ju je donijela upravna vlast na državnoj razini, karakteristike su joj jednake kao i kod ostalih općenormativnih akata koji su doneseni na lokalnoj razini.

12 „Generalnost nekog propisa znači samo da on može, danas - sutra, obuhvatiti svaki pojedini slučaj, pri kome će nastupiti od njega predviđena pravna situacija. Apstraktnost znači da se ona ne odnosi na neke konkretne, ma i neodređene slučajeve, već zamišlja posve apstraktno “ (Krbek, Ivo, Sudska kontrola naredbe, Jugoslavenska akademija znanosti i umjetnosti, Tisak zaklade tiskare Narodnih novina,1939., str. 12.).

13 Upravni akt može biti i generalan, ali nikada apstraktan (Krbek, Ivo, Diskreciona ocjena, Tisak nadbiskupske tiskare, Zagreb, 1937., str. 195.).

14 Krbek, Sudska kontrola naredbe, 1939., str. 11. - 12.

15 Borković, Ivo, Upravno pravo, VII. izmjenjeno i dopunjeno izdanje, Narodne novine, Zagreb, 2002., str. 63.

16 Krbek, Ivo, Upravno pravo, I. knjiga, Uvodna i osnovna pitanja, Tisak i naklada jugoslavenske štampe, Zagreb 1929., str. 106.

17 Krbek, Sudska kontrola naredbe, 1939., str. 12. - 15. 


\subsection{Sudska kontrola općenormativnih akata jedinica lokalne i područne (regionalne) samouprave}

Odredbe o općim aktima JLRS-a smještene su u prvi dio glave IX. ZLRS-a koji nosi naziv Akti jedinica lokalne i područne (regionalne) samouprave, u člancima 73. - 75. Nadzor nad njima normiran je u glavi X. Državni nadzor i zaštita lokalne i područne (regionalne) samouprave. ${ }^{18} \mathrm{U}$ okviru samoupravnog djelokruga lokalne jedinice, odnosno njihova predstavnička tijela, donose opće akte. ZLRS izrijekom spominje statut, poslovnik, proračun i druge opće akte.

18 Odredbe o općim aktima i nadzoru nad njima bile su uređene prvim Zakonom o lokalnoj samoupravi i upravi, NN 90/92, (dalje: ZLSU). Opći akti su bili normirani u glavi VII. podijeljenoj u dva dijela. Uz čl. 74., 75. i 76. koji su se odnosili na opće akte, u čl. 77. su bili regulirani pojedinačni akti.

Nadzor nad zakonitošću rada i općih akata predstavničkih tijela lokalne samouprave u njihovom samoupravnom djelokrugu obavljali su organi središnje državne uprave svako u svom djelokrugu na način i u postupku utvrđenima zakonom kojim se uređuje državna uprava. Ako bi nadležni organi središnje državne uprave ocijenili da je opći akt u suprotnosti s Ustavom ili zakonom, obustavili bi od izvršenja opći akt i predložili Vladi Republike Hrvatske da pokrene postupak pred Ustavnim sudom Republike Hrvatske (dalje: USUD) za ocjenu ustavnosti spornog akta (čl. 80. st. 1. ZLSU). Ako Vlada ne bi pokrenula postupak pred USUD-om u roku od 30 dana od dana obustave izvršenja općeg akta, prestala bi obustava izvršenja općeg akta (čl. 80. st. 2. ZLSU).

ZLSU je bio mijenjan tri puta, od čega su za ovaj rad važne izmjene iz 1999. (ZLSU '99.). U potpunosti su izmijenjeni čl. 80., 81. i 82. Nakon te izmjene, čl. 80. normira postupanje župana u pogledu ocjene zakonitosti općeg akta. Župan dobiva novu dužnost, i to obustaviti opći akt od primjene. On ocjenjuje zakonitost općeg akta, te kada ustanovi da je suprotan ustavu i zakonu, dužan je u roku od osam dana od dana dostave donijeti odluku o obustavi općeg akta. Odluka o obustavi općeg akta morala je biti obrazložena. Odluku o obustavi općeg akta moglo je neposredno donijeti i središnje tijelo državne uprave (dalje: STDU). Dostavljala se bez odlaganja općinskom načelniku, gradonačelniku, županijskom načelniku, predsjedniku predstavničkog tijela koje je donijelo akt (čl. 80. ZLSU '99). Članak 81. nalagao je županu da opći akt i odluku o obustavi bez odlaganja proslijedi središnjem tijelu državne uprave u čijem je djelokrugu pitanje koje se općim aktom uređuje, odnosno središnjem tijelu državne uprave za lokalnu samoupravu. STDU je trebalo ocijeniti opravdanost obustave općeg akta u roku od osam dana, a onu koju je smatralo opravdanom trebalo je proslijediti Vladi Republike Hrvatske. Ako je odluku o obustavi ocijenilo neopravdanom, ukinulo je odluku župana, te je svoju odluku dostavilo županu, općinskom načelniku, gradonačelniku, odnosno županijskom načelniku. $\breve{l}$. 82. bilo je propisano postupanje STDU-a kada ono obustavi opći akt, odnosno odluku o obustavi ocijeni opravdanom. Tada je trebalo predložiti Vladi Republike Hrvatske pokretanje postupka za ocjenu ustavnosti i zakonitosti, o čemu su se trebali obavijestiti župan $i$ jedinica lokalne samouprave. Ako Vlada taj postupak ne bi pokrenula u roku od 30 dana od dana primitka prijedloga za pokretanje postupka ocjene ustavnosti i zakonitosti, prestala bi obustava općeg akta (čl. 82. ZLSU '99).

Ako se usporede ZSLU i ZLSU '99, primjećuje se da je ZLSU-om bilo propisano tijelo koje je moglo u konačnici odlučiti o ustavnosti općih akata, ali ne i o njihovoj zakonitosti. To je bio USUD čiji je rad bio normiran Ustavnim zakonom o Ustavnom sudu iz 1991. Ovo je bila pogreška koja nije imala utjecaja na praksu jer je Ustavnim zakonom o Ustavnom sudu jasno bilo naznačeno da on kontrolira i zakonitost, doduše, drugih propisa s Ustavom i zakonom. ZLSU '99 uopće ne navodi koje je to tijelo zaduženo za ocjenu ustavnosti i zakonitosti. Naime, USUD se u tom zakonu uopće ne spominje u kontekstu nadzora nad općim aktima, a ne spominje se ni jedno drugo tijelo, tako da je nadležnost i dalje ostala u rukama USUD-a. 
Poslovnikom se uređuju prava i dužnosti članova, ${ }^{19}$ predsjednika i potpredsjednika predstavničkog tijela ${ }^{20}$ i način rada predstavničkog tijela. Donosi se većinom glasova svih članova predstavničkog tijela. ${ }^{21}$ Proračun je temeljni financijski akt JLRS. Donosi ga predstavničko tijelo JLRS u skladu s posebnim zakonom. Općinski načelnik, gradonačelnik, odnosno župan kao jedini ovlašteni predlagatelj predlaže predstavničkom tijelu donošenje proračuna, a podneseni prijedlog proračuna općinski načelnik, gradonačelnik, odnosno župan može povući i nakon glasovanja o amandmanima, a prije glasovanja o proračunu u cjelini. Proračun jedinice lokalne samouprave i jedinice područne (regionalne) samouprave dostavlja se Ministarstvu financija u skladu s posebnim zakonom (čl. 69. ZLRS-a). Također se, kao i statut, poslovnik i godišnji obračun, donosi većinom glasova svih članova predstavničkog tijela (čl. 36. st. 2. ZLRS-a).

Ustavnim zakonom o Ustavnom sudu u članku 37. uređen je institut ekscepcije ilegalnosti. Propisano je postupanje suda ako u svom radu primijeniti nezakonitost drugog propisa ili njegove pojedine odredbe koji mora primijeniti u konkretnom slučaju. Na konkretni slučaj sud će neposredno primijeniti zakon, a Ustavnom sudu uputit će zahtjev za ocjenu spornog propisa, odnosno pojedine njegove odredbe s Ustavom i zakonom. Međutim, navedeno uređenje ne bi trebalo promatrati na način da obuhvaća sve podzakonske općenormativne akte. USUD od stupanja na snagu ZUS-a jasno razlikuje pojmove „drugi propis“ od pojma „opći akt“ o čemu je dao svoje precizno stajalište u rješenju U-II-5157/2005 od 5. ožujka 2012. Prema tome, navedena odredba bi se trebala odnositi samo na podzakonske općenormativne akte koje donose tijela državne uprave, odnosno „druge propise“, a ne i tijela jedinica lokalne i područne (regionalne) samouprave. U slučaju ako bi sud primijetio nezakonitost općeg akta jedinice lokalne i područne (regionalne) samouprave te ga uputio na ocjenu USUD-u, on bi se proglasio nenadležnim te bi podnositelja uputio da podnese zahtjev VUS-u koji je nadležan za ocjenu zakonitosti općih akata jedinice lokalne i područne (regionalne) samouprave od stupanja na snagu ZUS-a 2012. Sukladno tome, svaki sud koji primijeti da se pred njim nalazi nezakoniti opći akt jedinice lokalne i područne (regionalne) samouprave, takav bi akt trebao uputiti VUS-u sukladno člancima 83. - 88. ZUS-a.

\subsubsection{Ustavnosudska kontrola statuta lokalnih i područnih jedinica}

Statut je najviši opći akt ${ }^{22}$ koji donosi predstavničko tijelo JLRS. ${ }^{23}$ Svi ostali akti JLRS moraju biti u skladu sa statutom, zakonom i Ustavom. Dakle, ako se

19 Čl. 31. st. 4. ZLRS-a.

20 Čl. 34. st. 5. ZLRS-a.

21 Čl. 33. ZLRS-a.

22 Donosi se u okviru samoupravnog djelokruga, a mora se kretati u okviru zakona (Banić, Slavica, Režim općih akata nakon donošenja Zakona o upravnim sporovima (2010.), Zbornik radova Pravnog fakulteta u Splitu, god. 50 (2013) 3; str. 577.).

23 Čl. 35. st.1. t. 1. Zakona o lokalnoj i područnoj (regionalnoj) samoupravi, NN 33/01, 60/01, 129/05, 109/07, 125/08, 36/09, 36/09, 150/11, 144/12, 19/13. 
pažljivo pročita odredba članka 5. stavka 1 . Ustava ne bi se smjelo protumačiti da je dovoljno da opći akti nisu suprotni zakonima nego se nailazi upravo na ", suglasnost ${ }^{24}$ zakona s Ustavom, a ostalih propisa s Ustavom i sa zakonom “. ${ }^{25}$ Ovdje je izvjesno da Ustav pod „ostalim propisima“ podrazumijeva i opće akte JLRS, a tim više i statut koji je u njihovoj hijerarhiji najviši. ${ }^{26}$ Iako u članku 136. Ustava nailazimo na to da JLRS ,,imaju pravo u okviru zakona, svojim statutima samostalno urediti unutarnje ustrojstvo i djelokrug svojih tijela ", to ne znači da akti ne bi trebali biti suglasni s Ustavom i zakonom. ${ }^{27}$

ZLRS-om je u članku 8. propisano da se statutom $^{28}$ podrobnije uređuje samoupravni djelokrug općine, grada, odnosno županije, njena obilježja, javna priznanja, ustrojstvo, ovlasti i način rada tijela, način obavljanja poslova, oblici konzultiranja građana, provođenje referenduma u pitanjima iz djelokruga, mjesna samouprava, ustrojstvo i rad javnih službi, oblici suradnje jedinica lokalne, odnosno područne (regionalne) samouprave te druga pitanja važna za ostvarivanje prava i obveza.

Postupak redovitog ${ }^{29}$ nadzora nad statutom ${ }^{30}$ propisan je ZLRS-om u članku

24 Istaknuli autori.

25 Tako i Medvedović govori o principu stroge ustavnosti i zakonitosti propisa i o obvezi svih donositelja normativnih akata da im akti budu u skladu s Ustavom i zakonom (Medvedović, Dragan, Nadzor izvršne vlasti nad aktima predstavničkih tijela jedinica lokalne samouprave u Republici Hrvatskoj, Javna uprava, 38 (2002 )2; str. 237. -238., Medvedović, Dragan, Kontrola ustavnosti i zakonitosti općih akata općina i gradova, Hrvatska javna uprava, 3 (2001) 3-4; str. 512. i Medvedović, Dragan, Nadzor izvršne vlasti nad općim aktima jedinica lokalne samouprave - de lege lata i de lege ferenda, Hrvatska javna uprava, 5 (2005) 1; str. 86.).

Slično o sukladnosti statuta s Ustavom i zakonom v. u: Tropina Godec, Željka, Još o nadzoru općih akata predstavničkih tijela jedinica lokalne i područne (regionalne) samouprave, Informator, br. 5439. od 22. travnja 2006., str. 16.

26 Arlović smatra da statuti ne moraju biti suglasni sa zakonom nego je dovoljno da statuti nisu protivni zakonu. Više u: Arlović, Mato, Ocjena zakonitosti općih akata u novom Zakonu o upravnim sporovima: o nekim otvorenim pitanjima, Pravni vjesnik, 27 (2011) 3-4; str. 134.

27 O suglasnosti općih akata s Ustavom i zakonom v. i: Sarvan, Desanka, Kontrola akata lokalnih i regionalnih vlasti, Riznica, (2010) 4; str. 48.

28 U podjeli na interne i eksterne opće akte, statut je kao temeljni opći akt javnopravnih tijela uvijek eksterni opći akt (Banić, Režim općih akata nakon donošenja Zakona o upravnim sporovima (2010), 2013., str. 580.).

29 Opći akti koji se donose i dostavljaju radi provedbe redovitog nadzora su statut, poslovnik, proračun ili drugi opći akt (Kasabašić, Štefanija, Državni nadzor i zaštita lokalne i područne (regionalne) samouprave, Nadzor općih akata predstavničkih tijela jedinica lokalne $i$ područne (regionalne) samouprave, Informator, br. 5435 od 8. travnja 2006., str. 7.).

30 Statut ima posebnu važnost u hijerarhiji izvora upravnog prava jer je najviši opći akt JLRS s kojim moraju biti u skladu svi ostali opći akti (Staničić, Frane, Đanić, Ana, Ocjena ustavnosti $i$ zakonitosti općih akata u hrvatskom pravu i praksa Visokog upravnog suda Republike Hrvatske, Hrvatska komparativna i javna uprava, 14 (2014) 4; str. 963.).

Rajko ovdje govori o ocjeni statutarnosti općih akata. V. u: Rajko, Alen, Ocjena zakonitosti i statutarnosti općih akata - bitna novina u okviru reformiranja upravnog spora, Hrvatska pravna revija, Upravno pravo, 11 (2011) 5; str. 38. 
82.a. ${ }^{31}$ Prema stavku 3. istoga članka, tijelo pred kojim se pokreće postupak ocjene suglasnosti statuta s Ustavom i zakonom je USUD ${ }^{32}$. O važnosti statuta govori i odredba članka 84. stavka 1. točke 2. ZLRS-a kojom je predviđeno da će doći do raspuštanja predstavničkog tijela ako ono u roku od 60 dana od konstituiranja ne donese statut. ${ }^{33}$

U rješenju U-II-5157/2005 od 5. ožujka 2012. USUD je potvrdio važnost statuta navodeći:

„Iznimka od pravila da se 'drugim propisima' u smislu članka 125. alineje 2. Ustava ne smatraju eksterni i interni opći akti koje donose tijela jedinica lokalne $i$ područne (regionalne) samouprave jesu statuti jedinica lokalne i područne (regionalne) samouprave. Zbog njihove važnosti za ostvarenje Ustavom zajamčenog prava građana na lokalnu i područnu (regionalnu) samoupravu (članak 4. stavak 1. i glava VI. Ustava), kontrola zakonitosti statuta jedinica lokalne i područne (regionalne) samouprave mora biti izuzeta iz nadležnosti Visokog upravnog suda Republike Hrvatske u smislu članka 3. stavka 2. ZUS-a i neposredno provedena u okviru kontrole ustavnosti i zakonitosti iz članka 125. alineje 2. Ustava."

USUD je, i prije donošenja citiranog rješenja, između ostalih općih akata, odlučivao i o statutima lokalnih jedinica podvodeći ih pod druge propise. Od 1999. do siječnja 2016. USUD je ocjenjivao ustavnost i zakonitost statuta lokalnih jedinica u osam slučajeva. ${ }^{34}$

$31 \mathrm{Na}$ nadzor zakonitosti statuta jedinica lokalne i područne (regionalne) samouprave odgovarajuće se primjenjuju odredbe članaka 80., 80.a, 80.b i 81. ZLRS-a.

Kad središnje tijelo državne uprave nadležno za lokalnu i područnu (regionalnu) samoupravu neposredno obustavi od primjene statut jedinice, odnosno kad odluku predstojnika o obustavi, odnosno potvrdi odluke općinskog načelnika, gradonačelnika, odnosno župana o obustavi od primjene statuta ocijeni osnovanom, predložit će bez odgode Vladi Republike Hrvatske da pokrene postupak za ocjenu suglasnosti statuta jedinice s Ustavom i zakonom pred USUDom.

Vlada Republike Hrvatske pokrenut će postupak za ocjenu suglasnosti statuta s Ustavom i zakonom pred USUD-om u roku od 30 dana od dana primitka prijedloga za pokretanjem postupka.

Ako Vlada Republike Hrvatske ne pokrene postupak za ocjenu suglasnosti statuta s Ustavom i zakonom pred Ustavnim sudom Republike Hrvatske u roku od 30 dana od dana primitka prijedloga za pokretanje postupka, prestaje obustava od primjene općeg akta.

32 Statuti JLRS-a su ustavna kategorija pa su morali biti pridržani kontroli USUD-a (Omejec, Banić, Diferencijacija propisa $i$ općih akata u budućoj praksi Ustavnog suda $i$ Upravnog suda u povodu Zakona o upravnim sporovima (2010.), Zbornik radova Pravnog fakulteta u Splitu, 49 (2012) 2; str. 319.)

33 Više o razlozima i posljedicama raspuštanja lokalnih predstavničkih tijela v. u: Crnković, Mateja, Raspuštanje lokalnih predstavničkih tijela, Hrvatska i komparativna javna uprava, 12 (2012) 3; str. 803. - 835. i Crnković, Novine u odnosu centralne države i lokalne samouprave - koliko i kakvog nadzora, 2013., str. 223. - 253.

34 V. U-II-81/1999 od 13. rujna 2000., U-II-2456/2001 od 18. rujna 2002., U-II-496/2003 od 5. lipnja 2007., U-II-425/2002 od 16. siječnja 2008., U-II-38101/2009 od 17. ožujka 2010., U-II-6110/2013 od 12. kolovoza 2014.,_U-II-1984/2010 od 4. studenoga 2014. i U-II4022/2010 od 2. lipnja 2015. 


\subsubsection{Sudska kontrola ostalih općenormativnih akata lokalnih i regionalnih jedinica}

Prije ulaska u materiju same kontrole akata jedinica lokalne i područne (regionalne) samouprave, potrebno je razmotriti postupak njihova donošenja budući da u njegovom tijeku mogu nastati pogreške koje će imati utjecaja na valjanost općih akata, primjerice manjak kvoruma predstavničkog tijela, slučaj u kojem akt donosi nenadležno tijelo, itd., što za posljedicu ima nezakonitost općeg akta jedinice lokalne i područne (regionalne) samouprave.

\subsubsection{Donositelj općih akata JLRS-a i postupak njihova donošenja}

U članku 133. stavku 2. Ustava propisuje se da se pravo na samoupravu ostvaruje preko lokalnih, odnosno područnih (regionalnih) predstavničkih tijela koja su sastavljena od članova izabranih na slobodnim i tajnim izborima na temelju neposrednog, jednakog i općega biračkog prava. Pri postavljanju koncepcije o lokalnoj samoupravi, Europska povelja o lokalnoj samoupravi u članku 3. stavku 2. navodi da će se pravo na lokalnu samoupravu provoditi preko vijeća ili skupština sastavljenih od članova izabranih na slobodnim i neposrednim izborima, tajnim glasovanjem na temelju općeg i jednakog biračkog prava. Nadalje, ta tijela mogu imati izvršna tijela koja su im odgovorna. Ova se odredba ne može nikako smatrati ograničavajućom u odnosu na primjenu zborova građana, referenduma ili drugog oblika neposrednog sudjelovanja građana tamo gdje je to dopušteno zakonom.

Jedinice lokalne samouprave prema članku 3. ZLRS-a su općine i gradovi, a jedinice područne (regionalne) samouprave su županije. Opće akte tih jedinica donose njihova predstavnička tijela. U općini je to općinsko vijeće, u gradu gradsko vijeće, a u županiji županijska skupština. ${ }^{35}$

Predstavničko tijelo se smatra konstituiranim izborom predsjednika na prvoj sjednici na kojoj je nazočna većina članova predstavničkog tijela (čl. 32.). Ono, uz članove ${ }^{36}$ ima predsjednika i potpredsjednika (čl. 34. st. 1.). ${ }^{37}$

\subsubsection{Sazivanje sjednica predstavničkog tijela}

Predsjednik predstavničkog tijela saziva sjednice predstavničkog tijela po potrebi, a najmanje jednom u tri mjeseca. Predsjednik ima mogućnost sjednicu sazvati i elektroničkim putem (čl. 37. st. 4. ZLRS-a). Redovito sazivanje sjednica koje je u rukama predsjednika predstavničkog tijela iznimno je važno

35 Čl. 27. u vezi s čl. 73. ZLRS-a.

36 Broj članova predstavničkog tijela JLRS-a je neparan, određuje se prema broju stanovnika pojedine jedinice sukladno čl. 28. ZLRS-a. Oni nemaju obvezujući mandat i nisu opozivi. Gradska skupština Grada Zagreba ima 51 člana (čl. 5. st. 2. Zakona o Gradu Zagrebu, NN $62 / 01,125 / 08,36 / 09)$.

37 Ako predstavničko tijelo ima dva potpredsjednika, u pravilu se biraju tako da se jedan potpredsjednik bira iz reda predstavničke većine, a drugi iz reda predstavničke manjine, na njihov prijedlog (čl. 34. st. 2.). 
za pravovremeno donošenje općih akata. ${ }^{38}$ Predsjednik je dužan sazvati sjednicu predstavničkog tijela na obrazloženi zahtjev najmanje jedne trećine članova predstavničkog tijela u roku od 15 dana od primitka zahtjeva. Ako je u tom roku ne sazove, sjednicu će na obrazloženi zahtjev najmanje trećine članova predstavničkog tijela sazvati općinski načelnik, gradonačelnik ili župan u roku od osam dana. ${ }^{39}$ Po proteku toga roka, sjednicu može sazvati na obrazloženi zahtjev najmanje jedne trećine članova predstavničkog tijela, čelnik središnjeg tijela državne uprave nadležnog za lokalnu i područnu (regionalnu) samoupravu. Sjednica predstavničkog tijela mora se održati u roku od 15 dana od dana sazivanja. Ako je sjednica sazvana protivno ovim odredbama, smatra se nezakonitom, a doneseni akti ništavima (čl. 34. ZLRS).

Sjednice predstavničkih tijela su javne, ali postoji mogućnost isključenja javnosti u iznimnim slučajevima koji su predviđeni posebnim zakonima i općim aktom jedinice. $\mathrm{Na}$ sjednicama predstavničkog tijela glasuje se javno, ako predstavničko tijelo ne odluči da se, u skladu s poslovnikom ili drugim općim aktom, o nekom pitanju glasuje tajno. Poslovnikom o radu predstavničkog tijela uredit će se osiguranje praćenja rasprave i sudjelovanje u radu i odlučivanju (čl. 37. ZLRS).

\subsubsection{Djelokrug predstavničkog tijela}

Predstavničko tijelo u svom djelokrugu donosi statut JLRS-a i donosi odluke i druge opće akte kojima uređuje pitanja iz samoupravnog djelokruga JLRS. Ono osniva radna tijela, bira i razrješuje članove tih tijela te bira, imenuje i razrješuje i druge osobe određene zakonom, drugim propisom ili statutom, uređuje ustrojstvo i djelokrug upravnih tijela JLRS, osniva javne ustanove i druge pravne osobe za obavljanje gospodarskih, društvenih, komunalnih i drugih djelatnosti od interesa za jedinicu lokalne, odnosno područne (regionalne) samouprave te obavlja i druge poslove koji su zakonom ili drugim propisom stavljeni u djelokrug predstavničkog tijela (čl. 35. ZLRS).

\subsubsection{Odlučivanje predstavničkog tijela}

Način odlučivanja predstavničkog tijela uređen je člankom 36. ZLRS-a. Predstavničko tijelo donosi odluke većinom glasova ako je na sjednici nazočna većina članova predstavničkog tijela. Statut jedinice lokalne i područne (regionalne) samouprave, proračun i godišnji obračun donose se većinom glasova svih članova

38 Jedan od razloga za raspuštanje predstavničkog tijela nemogućnost je donošenja odluka dulje od tri mjeseca. Prvenstveno se tu uzima u obzir nemogućnost donošenja proračuna i godišnjeg obračuna. Razlog za nedonošenje je u tome što se predstavničko tijelo ne sastaje. Predstavnička tijela su zbog tog razloga bila raspuštena 12 puta u razdoblju od 1993. do 2010. Više u: Crnković, Raspuštanje lokalnih predstavničkih tijela, 2012., str. 803. - 836.

39 Prema čl. 37. st. 2. ZLRS-a sjednicama prisustvuje općinski načelnik, gradonačelnik, odnosno župan. 
predstavničkog tijela. Poslovnikom predstavničkog tijela mogu se odrediti druga pitanja o kojima se odlučuje većinom glasova svih članova predstavničkog tijela.

Ovaj kratki prikaz donošenja općih akata u JLRS-u napravljen je zbog toga što VUS ocjenjuje opće akte koje donosi JLRS, u skladu sa svojim kriterijima, poštujući odredbe ZUS-a i ZLRS-a.

Za kontrolu ostalih općih akata nadležan je VUS od stupanja na snagu ZUS-a 2012. ZUS-om je propisano u članku 3. stavku 2. da u nadležnost VUS-a ulazi ocjena zakonitosti općih akata tijela jedinica lokalne i područne (regionalne) samouprave. Ovakva regulacija koja je na prvi pogled sasvim jasna, u praksi je izazvala probleme. Budući da nije precizno regulirano o kojim je točno tijelima u lokalnoj samoupravi riječ, moguće je bilo zauzeti dva različita stajališta. Prema prvom, opći akti su oni koje donose isključivo predstavnička tijela jedinica lokalne i područne (regionalne) samouprave prema točno određenoj proceduri, oni se objavljuju i stupaju na snagu, sukladno ZLRS-u. Međutim, prema drugom, širem gledištu, opći akti su akti i drugih lokalnih tijela ako se odnose na širi krug adresata te ako su apstraktni. Problem nastaje ako akt koji je trebalo donijeti predstavničko tijelo donese neko drugo, nenadležno tijelo. U ovakvim je slučajevima došlo do odbacivanja zahtjeva za ispitivanje zakonitosti općih akata od strane VUS-a. Primjerice, problem nastaje kada se u ulozi donositelja akta koji odgovara svim karakteristikama općeg akta, pojavi neko drugo tijelo, primjerice gradonačelnik. Mogu se razlikovati dva slučaja. Prvi, u kojem gradonačelnik manipulira svojom ovlasti jer njegove akte ne kontrolira VUS pa donosi opće akte iako je to u nadležnosti predstavničkog tijela. Predstavničko tijelo je kolegij s najmanje sedam članova ${ }^{40}$ koji donosi opće akte u ime građana. Stoga je nezakoniti onaj akt koji donosi gradonačelnik kao izvršno tijelo jer je njegova uloga izvršavati ili osigurati izvršavanje odluka predstavničkog tijela. ${ }^{41}$ Ako se ove dvije uloge pomiješaju, ide se suprotno volji građana, time se mogu narušiti njihova prava, a VUS bi to mogao izbjeći i nešto širim tumačenjem odredbe članka 3. stavka 2. ZUS-a. Primjerice, u francuskom pravu ovaj oblik nezakonitosti ulazi u nenadležnost ratione materiae te je kao takav jedan od temelja za podnošenje tužbe zbog prekoračenja ovlasti. ${ }^{42}$ Općenito, kontrola zakonitosti općih akata u Francuskoj temelji se na tri načela. Prvo, provodi se nad aktima koji su već na snazi, drugo, odnosi se samo na zakonitost, ne i na pravovremenost akta, i treće, ako se prefekt $t^{43}$ pozove na nezakonitost, jedino tijelo koje može poništiti akt je sud. ${ }^{44}$ Donošenje pravnog akta u ovlasti je lokalnih predstavnika. Međutim, taj akt ostaje podređen kontroli predstavnika države koji ocjenjuje njegovu suglasnost

40 Čl. 28. st. 1. alineja 1. ZLRS-a.

41 Čl. 48. st. 1. t. 2. ZLRS-a.

42 Rouault, Marie - Christine, Contentieux administratif, Gualino éditeur, Paris, 2006., str. 171.

43 U Francuskoj upravnu kontrolu akata lokalnih jedinica provodi prefekt koji predstavlja cijelu vladu unutar svakog departmana (Allemand, Roselyne, Les modalités du contrôle administratif des actes locaux dans six Etats de l'Union Européenne, Revue française de droit administratif, 24 (2008) 2; str. 289.

44 Gjidara, Marc, Le côntrole des actes des autorités locales par les tribunaux administratifs en France, Zbornik radova Pravnog fakulteta u Splitu, 47 (2010) 3; str. 552. 
sa zakonom i može izazvati njegovo poništenje od strane suca. Kontrola zakonitosti provodi se nad svim lokalnim tijelima, lokalnim javnim ustanovama, i nad aktima koje ta tijela donose. ${ }^{45}$ Kod akata koje donose lokalna tijela razlikuju se oni koji se obvezatno podnose na potvrdu prefektu od onih kod kojih takva potvrda nije obavezna (la distinction entre les actes soumis à transmission obligatoire et les actes non soumis à cette obligation), a sukladno toj podjeli, prefekt ima različite ovlasti u provođenju upravne kontrole.

Drugi problematični slučaj u hrvatskom sustavu postoji kada je gradonačelnik ustinu ovlašten donijeti akt, koji je po svojim karakteristikama općenormativni akt. ${ }^{46}$ Međutim, takav akt neće biti podvrgnut nikakvoj kontroli jer nju ne provodi VUS, a ni neko drugo sudsko tijelo. Ovdje bi VUS svoju nadležnost mogao temeljiti na rješenju U-II-5157/2005 od 5. ožujka 2012. prema točki 3. gdje USUD navodi da u doseg kontrole VUS-a ulaze čak i interni opći akti koje donose tijela jedinica lokalne i područne (regionalne) samouprave, druge pravne osobe s javnim ovlastima i pravne osobe koje obavljaju javnu službu u smislu članka 3. stavka 2. ZUS-a.

Istraživanjem se dolazi do zaključka da čelnici JLRS-a donose nemali broj takvih akata. Riječ je, primjerice, o različitim pravilnicima, ${ }^{47}$ zaključcima, ${ }^{48}$ odlukama, ${ }^{49}$ itd. Za navedene akte nije predviđena kontrola zakonitosti, što stvara širok spektar akata kojima se mogu povrijediti subjektivna prava građana, a ne postoje zakonski mehanizmi da se njihove donositelje u tome spriječi. Unutar pravnih osoba koje obavljaju javnu službu i pravnih osoba s javnim ovlastima donositelji općih akata najčešće su ravnatelji i upravna vijeća ${ }^{50}$, a problemi izazvani nepreciznom regulacijom dolaze i tu do izražaja. ${ }^{51}$

\subsubsection{Specifičnosti sudske kontrole prostornih planova}

Iako se u ZLRS-u izrijekom ne navode kao opći akti, posebnu pažnju valja posvetiti prostornim planovima koji svojom dvojbenom pravnom prirodom izazivaju znatan interes stručnjaka i javnosti. Neki stručnjaci smatraju da nije riječ

45 Ibid., str. 553.

46 V. primjerice Pravilnik o unutarnjem redu prema čl. 4. Zakona o službenicima i namještenicima u lokalnoj i područnoj (regionalnoj) samoupravi, NN 86/08, 61/11.

47 V. primjerice Pravilnik o davanju poticaja za razvoj poljoprivrede, ruralni razvoj i unapređenje lovstva na području Grada Samobora, Službene vijesti Grada Samobora, br. 1 od 16. siječnja 2015., Pravilnik o uvjetima i postupku za dodjelu financijskih potpora za programe i projekte organizacijama civilnog društva iz Proračuna Grada Ludbrega, Službeni vjesnik Varaždinske županije, br. 2/2015.

48 V. primjerice Zaključak o ostvarivanju prava na sufinanciranje prijevoza umirovljenika koji imaju prebivalište na području Grada Samobora, Službene vijesti Grada Samobora, br. 1 od 16. siječnja 2015.

49 V. primjerice Odluku o zabrani spaljivanja smeća, korova, suhe trave i drugih poljoprivrednih $i$ šumskih otpadaka i ostataka biljaka nakon žetve i berbe, te loženje vatre u šumama i blizini šume, Službeni glasnik Međimurske županije, br. 3/2015.

50 V. primjerice čl. 53. i 54. Zakona o ustanovama, Narodne novine, br. 76/93, 29/97, 47/99, $35 / 08$.

51 V. primjerice Rješenje VUS-a Usoz-5/2012-7 od 12. lipnja 2013. 
o općim aktima, dok drugi zagovaraju njihovu pravnu prirodu općeg akta. Zakon o prostornom uređenju (dalje: ZPU) ${ }^{52}$ u članku 58. stavku 1. navodi da prostorni planovi imaju snagu i prirodu podzakonskog propisa. Tu se ne bi smjelo automatski složiti sa zakonodavčevom regulacijom o drugom propisu, nego pri razmatranju pravne prirode prostornog plana, treba uzeti u obzir ustavna i zakonska rješenja o djelokrugu JLRS-a.

U dodjeljivanju poslova iz samoupravnog djelokruga prihvaćeno je načelo supsidijarnosti i metoda opće klauzule (čl. 135. st. 3. Ustava i čl. 19. ZLRS-a). ${ }^{53}$ Riječ je o poslovima koji su u samoupravnom djelokrugu JLRS-a pa tako ZLRS $\mathrm{u}$ članku 19. navodi da ,općine $i$ gradovi ${ }^{54}$ u svom samoupravnom djelokrugu obavljaju poslove lokalnog značaja kojima se neposredno ostvaruju potrebe građana, a koji nisu Ustavom ili zakonom dodijeljeni državnim tijelima i to osobito poslove koji se odnose na uređenje naselja i stanovanje, prostorno $i$ urbanističko planiranje... “U samoupravnom djelokrugu županija su poslovi od područnog značaja, a između ostalih, tu je i prostorno i urbanističko planiranje (čl. 20. ZLRS-a). Radman kritizira takvo uređenje jer se u slučaju urbanističkog planiranja kod županija ne može smatrati da je riječ o poslovima od područnog ili regionalnog značenja, zbog samog karaktera i značenja urbanističkog planiranja i urbanističkog plana, što za posljedicu ima preklapanje nadležnosti, prevelike ovlasti županija, te ostale posljedice koje štete autonomiji ${ }^{55}$ lokalne samouprave. ${ }^{56}$

Prostorni plan je opći akt predstavničkog tijela ${ }^{57}$ i kao takav ima određene posebnosti. ${ }^{58}$ On spada u najsloženije opće pravne akte koje donose jedinice lokalne samouprave, a pravo i dužnost njihova donošenja jedan su od najvažnijih instrumenata iz djelokruga jedinica lokalne samouprave. ${ }^{59}$

USUD je odlučivao o zakonitosti i ustavnosti prostornih planova u svojim brojnim odlukama i rješenjima. ${ }^{60}$

52 Zakon o prostornom uređenju, NN 153/13.

53 Radman, Zoran, Ostvarivanje prava na lokalnu samoupravu u prostornom uređenju, Hrvatska javna i komparativna uprava, 14 (2014) 1; str. 106.

54 Prema čl. 19.a st. 2. ZLRS-a u odnosu na ovu materiju, isti djelokrug imaju i veliki gradovi.

55 O zatiranju autonomije lokalne samouprave v.: Medvedović, Nadzor izvršne vlasti nad općim aktima jedinica lokalne samouprave - de lege lata i de lege ferenda, 2005., str. 102., Koprić, Ivan, Proširenje djelokruga i sužavanje nadzora središnjih državnih organa, Hrvatska javna uprava, 2 (2000) 3; str. 391. - 436.

56 Više o toj nepreciznosti i preklapanju nadležnosti lokalnih i regionalnih tijela v. u: Radman, Ostvarivanje prava na lokalnu samoupravu u prostornom uređenju, 2014., str. 107. - 110. i 115. -120 .

57 O kontroli nad prostornim planovima od strane državnih tijela v. Radman, Ostvarivanje prava na lokalnu samoupravu u prostornom uređenju, 2014., str. 110. - 114. i Bienenfeld, Josip, Izrada i donošenje prostornih planova u jedinicama lokalne i područne samouprave, HGK - Sektor za trgovinu, Jedanaesti forum poslovanja nekretninama, 2006., str. 33. - 35.

58 Radman, Ostvarivanje prava na lokalnu samoupravu u prostornom uređenju, 2014., str. 110.

59 Bienenfeld, Izrada $i$ donošenje prostornih planova u jedinicama lokalne $i$ područne samouprave, 2006., str. 18.

60 V. primjerice: U-II-921/1994 od 4. srpnja 2001., U-II-1075/2000 od 18. travnja 2007., U-II2970/2004 od 11. srpnja 2007., U-II-2559/2006 od 27. veljače 2008., U-II-3454/2005 od 16. 
U Odluci U-II-1892/2000 od 12. travnja 2001. USUD je ukinuo sedam akata. Utvrdio je da pri donošenju osporenih općih akata, odnosno izmjena predmetnih prostornih planova, nadležna tijela nisu poštovala zakonom propisani postupak. Navedeni osporeni akti bili su prostorni planovi u smislu odredbe članka 57. stavka 1. Zakona o prostornom uređenju. ${ }^{61}$ Nad njima je bio proveden nadzor sukladno ZLRS-u te je Ministarstvo zaštite okoliša i prostornog uređenja rješenjem ${ }^{62}$ obustavilo od izvršenja osporene prostorne planove. Bio je proveden redoviti nadzor, kojim je potvrđena odluka Ministarstva. Donoseći osporene propise na način u kojem se nije poštovao zakonom propisani postupak, nadležna tijela postupila su protivno odredbi članka 135. stavka 3. Ustava i time povrijedila odredbe članka 3. i 5. Ustava (t. 7. Odluke U-II-1892/2000).

USUD je Odlukom U-II-1610/2003 od 28. rujna 2004. ukinuo Odluku o donošenju Detaljnog plana uređenja prostora Trumbićeva obala - Dražanac u Splitu ${ }^{63}$ koju je donijelo Gradsko vijeće Grada Splita, a bila je podvrgnuta postupku redovitog nadzora te ju je obustavio Ured državne uprave u Splitsko dalmatinskoj županiji. Tu je obustavu potvrdilo Ministarstvo pravosuđa, uprave i lokalne samouprave Republike Hrvatske. Za ovaj je rad važna točka 7.3. u kojoj USUD navodi da on može ocjenjivati samo zakonitost podnesene mu Odluke budući da ona jest propis podložan ustavnosudskoj ocjeni ${ }^{64}$ pa se u tom smislu, a u svezi s Programom mjera, može ocjenjivati jedino s gledišta jesu li njezinom donošenju prethodili dokumenti koji prema zakonu moraju biti prethodno doneseni, jer ti dokumenti, prema odredbama Zakona o prostornom uređenju, ${ }^{65}$ imaju značaj postupovne pretpostavke, bez čijeg ispunjenja nije mogla biti donesena niti osporena Odluka. Iako USUD ovdje o prostornom planu kaže da je on ,propis podložan ustavnosudskoj ocjeni“", upravo suprotno navodi u spomenutoj Odluci U-II-1892/2000 od 12. travnja 2001. gdje je izrijekom rekao da je prostorni plan opći akt.

U Odluci U-II-4833/2005 od 21. veljače 2007. kojom je USUD odbio podnositelja, o Generalnom urbanističkom planu rekao je sljedeće:

„, Generalni urbanistički plan (u daljnjem tekstu: GUP) dokument je prostornog uređenja (prostorni plan) koji ima snagu i pravnu narav podzakonskog propisa. Njime se utvrđuje temeljna organizacija prostora, zaštita prirodnih, kulturnih $i$ povijesnih vrijednosti, korištenje $i$ namjena površina s prijedlogom prvenstva njihovog uređenja; sadrži način i oblike zaštite $i$ korištenja, uvjete

travnja 2008., U-II-3648/2007 od 30. travnja 2008., U-II-3441/2005 od 22. prosinca 2009., U-II-3656/2006 od 29. lipnja 2010., U-II-57/2006 od 25. siječnja 2011., U-II-2574/2005 od 15. veljače 2011. - u t. 6. Obrazloženja ove odluke USUD je istaknuo da donositelji podzakonskih propisa nisu ovlašteni donositi vjerodostojna tumačenja propisa).

61 Ocjenjivala se suglasnost sa Zakonom o prostornom uređenju, NN 30/94, 68/98 i 61/00.

62 Klasa: 362-01/00-02/0028, ur. broj: 531-01-00-4 od 20. studenoga 2000.

63 Odluka o donošenju Detaljnog plana uređenja prostora Trumbićeva obala - Dražanac u Splitu, Službeni glasnik Grada Splita, broj 12/01.

64 Istaknuli autori.

65 Zakon o prostornom uređenju, NN 30/94, 68/98, 61/00, 32/02. 
i smjernice za uređenje $i$ zaštitu prostora, mjere za unapređenje $i$ zaštitu okoliša, područja s posebnim prostornim i drugim obilježjima te druge elemente od važnosti za područje za koje se donosi (članak 25. ZPU-a). ${ }^{66}$ Člankom 26. ZPU-a propisano je da Generalni urbanistički plan Grada Zagreba donosi Gradska skupština Grada Zagreba prema postupku propisanom člankom 24. tog Zakona. “

I Rješenjem U-II-3655/2006 od 29. lipnja 2010. ${ }^{67}$ Ustavni je sud naveo da dokumenti prostornog uređenja imaju snagu i pravnu prirodu podzakonskog propisa (t. 5.) ${ }^{68}$ Osim toga, USUD je rekao da nije nadležan za ocjenu suglasnosti s Ustavom zakona, odnosno suglasnosti s Ustavom i zakonom drugog propisa sa stajališta da je njegov donositelj u samome propisu nešto propustio urediti (propisati) (t. 11.). Napomenuo je i da međusobna usklađenost odredaba nekog propisa ne može biti predmet ustavnosudske kontrole u smislu članka 128. Ustava (t. 12.).

Rješenjem U-II-1586/2014 od 9. travnja 2014. USUD se u točki 1. proglasio nenadležnim za odlučivanje o suglasnosti sa zakonom Odluke o donošenju urbanističkog plana uređenja neizgrađenog dijela naselja Podgora - Veliko Brdo ${ }^{69}$ te Odluke o donošenju ciljanih izmjena Urbanističkog plana uređenja neizgrađenog dijela naselja Podgora - Veliko Brdo. ${ }^{70}$ U t. 2. navodi da je i dalje nadležan za odlučivanje o suglasnosti drugih propisa s Ustavom i zakonom, a da je stupanjem na snagu Zakona o upravnim sporovima 1. siječnja 2012. ocjena zakonitosti općih akata $^{71}$ jedinica lokalne i područne (regionalne) samouprave u nadležnosti VUS-a.

Iz ove odluke jasno proizlazi da USUD prostorne planove smatra općim aktima. ${ }^{72}$ Međutim, cjelokupna nesređenost oko pravne prirode je nastala, osim zbog zakonskog uređenja u kojem se prostorni planovi izrijekom nazivaju podzakonskim propisima, i zbog prakse USUD-a koji je neodlučan u tom pogledu. USUD prostorne planove često naziva podzakonskim aktima. Oni jesu podzakonski akti, ali ne oni koje donose tijela državne vlasti, nego podzakonski akti - opći akti koje donose JLRS. Dakle, situacija bi trebala biti jasna. Ako se kao kriterij razlikovanja drugog propisa i općeg akta uzme norma o nadležnosti, tj. donositelj akta, prostorni planovi su sasvim sigurno opći akti jer su njihovi donositelji predstavnička tijela JRLS-a.

66 Zakon o prostornom uređenju, NN 30/94, 68/98, 61/00, 32/01, 100/04.

67 USUD je ispitivao ustavnost i zakonitost Usklađenja Prostornog plana Primorsko-goranske županije, (Službene novine Primorsko-goranske županije, broj 12/05.) te je utvrdio da je suglasano s Ustavom i zakonom.

68 Isto je stajalište USUD zauzeo u Rješenju U-II-3462/2007 od 25. listopada 2010.

69 Odluka o donošenju urbanističkog plana uređenja neizgrađenog dijela naselja Podgora Veliko Brdo, Glasnik - službeno glasilo Općine Podgora, broj 7/13.

70 Odluke o donošenju ciljanih izmjena Urbanističkog plana uređenja neizgrađenog dijela naselja Podgora - Veliko Brdo, Glasnik - službeno glasilo Općine Podgora, broj 20/13.

71 Istaknuli autori.

72 Djelomično suprotno smatra Medvedović zbog ustavnosudske prakse do 2005. u pogledu akata prostornog uređenja (Medvedović, Nadzor izvršne vlasti nad općim aktima jedinica lokalne samouprave - de lege lata i de lege ferenda, 2005., str. 89.). 
Po stupanju na snagu ZUS-a ocjenu zakonitosti prostornih planova preuzeo je VUS. ${ }^{73}$ Tako je primjerice rješenjem Usoz-47/2012- $6^{74}$ obustavio postupak jer predmetni opći akt više nije bio na snazi. ${ }^{75}$ Ovdje se može istaknuti Rješenje Usoz5/2012-7 od 12. lipnja 2013., gdje se radilo o Usklađenju Prostornog plana Splitsko - dalmatinske županije s Uredbom o uređenju i zaštiti zaštićenog obalnog područja mora $^{76}$ i Ispravka usklađenja Prostornog plana Splitsko-dalmatinske županije s Uredbom o uređenju i zaštiti zaštićenog obalnog područja mora. ${ }^{77}$ VUS je odbacio zahtjev jer je akte donio ravnatelj Županijskog zavoda za prostorno uređenje pa predmetni akti nisu opći akti. ${ }^{78} \mathrm{Iz}$ ove odluke proizlazi strogo poštovanje norme o nadležnosti kao kriterija za odlučivanje o prirodi podzakonskog akta.

U Rješenju Usoz-147/2012-6 od 21. veljače 2014. pogrešno je naznačeno da je do obustave došlo prema članku 88. stavku 1. ZUS-a jer je akt prestao važiti. ${ }^{79}$ Naime, ispada da je podnositelj povukao zahtjev što ovdje nije bio slučaj. VUS bi trebao biti oprezniji u navođenju članaka temeljem kojih je odlučivao. ${ }^{80,81}$

73 VUS je usvojio zahtjeve u presudama koje su se odnosile na prostorne planove, primjerice Usoz-75/2012-7 od 25. listopada 2013. (zahtjev je djelomično usvojen), Usoz-13/2012-12 od 28. siječnja 2014., Usoz-203/2012-5 od 28. ožujka 2014., Usoz-43/2012-21 od 30. svibnja 2014., Usoz-140/2012-10 od 30. svibnja 2014., Usoz-141/2012-8 od 30. svibnja 2014.

Odbio je zahtjeve u sljedećim presudama, Usoz-110/2012-10 od 25. listopada 2013., Usoz57/2012-9 od 26. studenoga 2013., Usoz-146/2012 od 21. veljače 2014., Usoz-76/2012-10 od 28. ožujka 2014., Usoz-98/2012-10 od 28. ožujka 2014., Usoz-116/2012-6 od 28. ožujka 2014., Usoz-107/2012-7 od 30. svibnja 2014.

Vus je odbacio zahtjeve u rješenjima Usoz-192/2012-6 od 28. ožujka 2014., Usoz-193/20126 od 28. ožujka 2014., Usoz-194/2012-6 od 28. ožujka 2014., Usoz-197/2012-8 od 28. ožujka 2014., Usoz-326/2013-9 od 28. ožujka 2014.

74 Četvrta sjednica Vijeća od 24. travnja 2013. Vijeće je odlučivalo o zakonitosti Odluke o donošenju prostornog plana Istarske županije, objavljenoj u Službenim novinama Istarske županije br. 10/02.

75 Do obustave vezano uz materiju prostornih planova došlo je i kod sljedećih odluka VUS-a: Usoz-109/2012-9 od 25. listopada 2013., Usoz-111/2012-7 od 26. studenoga 2013., Usoz33/2012-11 od 28. siječnja 2014., Usoz-147/2012-6 od 21. veljače 2014., Usoz-71/2012-7 od 29. travnja 2014., Usoz-93/2012-14 od 29. travnja 2014.

76 Uredba o uređenju i zaštiti zaštićenog obalnog područja mora, Službeni glasnik Splitskodalmatinske županije broj 5/05.

77 Uredba o uređenju i zaštiti zaštićenog obalnog područja mora, Službeni glasnik Splitskodalmatinske županije, broj 5/06.

78 Predmetni podzakonski akt nije opći ni u odluci Usoz-4/2012-6 od 18. lipnja 2013. jer je donositelj također ravnatelj Županijskog zavoda za prostorno uređenje, dakle, osoba koja nema zakonskog ovlaštenja za donošenje općeg akta kakav je dokument prostornog uređenja.

79 Marković upozorava kako prestankom važenja jednog propisa ne prestaju istodobno i pravni odnosi koji su nastali na temelju tog propisa (Marković, Sandra, Pravni režim prijelaznih (i završnih) odredaba pravnih propisa u praksi Ustavnog suda Republike Hrvatske, List Infomator, br. 5821 od 19. 12. 2009., str. 19.).

Iako se rad odnosio na režim prijelaznih i završnih odredaba propisa u praksi USUD-a, dobro je i ovdje to imati na umu.

80 Slična situacija i u odlukama Usoz-105/2012-7 od 21. veljače 2014., Usoz-111/2012-7 od 26. studenoga 2013.

81 Ostala rješenja VUS-a u kojima je došlo do obustave su: Usoz-29/2013-3, Usoz-30/2013-3, Usoz-31/2013-3, Usoz-48/2013-3, Usoz-49/2013-3, Usoz-50/2013-3, Usoz-51/2013-3 od 26. 
Nakon ove analize, može se zaključiti da bi zakonodavac paralelno trebao intervenirati u dva smjera. Prvo, odredba članka 58. ZPU-a koja glasi:

„Prostorni planovi imaju snagu i pravnu prirodu podzakonskog propisa.“

trebala bi biti izmijenjena i propisivati sljedeće: akta."

„Prostorni planovi su po snazi ispod zakona i imaju pravnu prirodu općeg

Drugo, odredba članka 83. stavka 1. ZUS-a koja glasi:

„Postupak ocjene zakonitosti općeg akta Visoki upravni sud pokreće na zahtjev fizičke ili pravne osobe ili skupine osoba povezanih zajedničkim interesom ako je pojedinačnom odlukom javnopravnog tijela koja se temelji na općem aktu došlo do povrede njihova prava ili pravnog interesa. Zahtjev se podnosi u roku od 30 dana od dostave odluke. "

trebala bi biti izmijenjena i propisivati sljedeće:

„Postupak ocjene zakonitosti općeg akta Visoki upravni sud pokreće na zahtjev fizičke ili pravne osobe ili skupine osoba povezanih zajedničkim interesom ako smatraju da bi opći akt neposredno ili da bi na općem aktu temeljene pojedinačne odluke javnopravnih tijela mogle dovesti do povrede njihova prava ili pravnog interesa. “

Dodatni argument koji podupire izmjenu članka 83. stavka 1. ZUS-a je činjenica da je tijelo koje ima najsličniju zadaću Vijećima za zakonitosti općih akata USUD, koji u ocjeni zakonitosti i ustavnosti drugih propisa ne traži dostavu pojedinačnih odluka javnopravnih tijela kojima bi podnositelji, odnosno predlagatelji učinili vjerojatnim povredu prava odnosno pravnog interesa.

Primjerice, u Njemačkoj je situacija jasnija. U Njemačkoj opće akte ${ }^{82}$ donose autonomne pravne osobe kao što su lokalne jedinice ili profesionalne organizacije koje su uređene kao pravne osobe javnoga prava s ciljem organiziranja vlastitog djelokruga ${ }^{83}$ Općine su ovlaštene, a u nekim slučajevima obvezane, donositi pravne norme u obliku općih akata, primjerice statute, proračune, planove građenja, prihode u obliku općih akata koji su doneseni temeljem određenih dohodovnih propisa na državnoj razini, ili uvjeta za korištenje javnih službi. Komunalnim propisima

rujna 2014., Usoz-133/2013-3, Usoz-134/2013-3, Usoz-135/2013-3, Usoz-136/2013-3, Usoz138/2013-3, Usoz-139/2013-3, Usoz-140/2013-3 od 3. listopada 2014., Usoz-80/2013-4, Usoz-81/2013-4, Usoz-84/2013-3, Usoz-85/2012-7 od 28. studenoga 2014., Usoz-54/2012-6, Usoz-213/2013-3, Usoz-330/2013-5 od 22. prosinca 2014.

82 Detaljan pregled općih akata koji ulaze u doseg kontrole prema čl. 47. st. 1. br. 2. v. u Quaas, Michael, Zuck, Rüdiger, Prozesse in Verwaltungssachen, 2. izdanje, Nomos, Baden-Baden, 2011., str. 692. -696.

83 Reimann, Mathias, Zekoll, Joachim, Introduction to German Law, 2. izdanje, Kluwer Law International, Haag 2005., str. 92. 
postavljeno je niz uvjeta s kojima opći akti moraju biti sukladni. Opći akti moraju biti doneseni u obliku odluka općinskog vijeća koje treba objaviti u službenom glasniku ili službenim novinama, a neki važniji opći akti trebaju potvrdu nadzornog tijela. Ispravci takvih akata mogući su prema posebnoj proceduri. U opće akte u Njemačkoj ulaze i urbanistički plan i plan građenja.

Urbanistički plan (Flächennutzungsplan) predviđa osnovne smjernice za uporabu zemljišta unutar pojedine lokalne jedinice. Određuje područja koja će biti iskorištena kao zemljišta za ustanove kojima je cilj zaštita javnog interesa, primjerice bolnice, škole, itd., zatim područja koja su predodređena u prometne svrhe te zelene površine i prirodne rezervate. ${ }^{84}$ Urbanistički plan donosi se prije plana o građenju i obvezuje tijela koja su ga donijela. Ovdje se u prvom redu to odnosi na lokalne vlasti, na susjedne lokalne jedinice koje su sudjelovale u njegovoj izradi i nisu opovrgle taj plan. Građani ne moraju izravno biti zahvaćeni tim planom. ${ }^{85}$

Najvažnija vrsta općih akata koji prema BauGB-u ulaze u doseg kontrole prema članku 47. stavku 1. br. 1. su planovi o građenju (Bebaungspläne) koji su uređeni člankom 10. stavkom 1. BauGB ${ }^{86}$ Urbanistički plan je temelj za plan o građenju (Bebaungsplan). Planovi građenja se izdaju u obliku općih akata prema članku 10. BauGB-a. Oni detaljno određuju iskorištavanje zemljišta općine (čl. 8. 13. BauGB) te vrstu (npr. stambeni ili poslovni prostor) i dimenziju zgrada (veličinu i visinu). Određuju i koji će prostor imati posebnu namjenu (čl. 9. BauGB) zbog zaštite od narušavanja plana izgradnjom novih zgrada za vrijeme procesa planiranja, lokalne vlasti mogu odgoditi rješavanje o zahtjevima za građevinske dozvole, zabraniti bilo kakvu gradnju na tom području, mogu zabraniti parcelaciju zemljišta i mogu iskoristiti pravo prvokupa sukladno zakonu (čl. 24. - 28. BauGB).

Planom građenja je predviđena zakonska dopustivost građenja. Svatko tko namjerava izgraditi zgradu mora postupati sukladno planu o građenju. Primjerice, ne može se izgraditi poslovna zgrada na zemljištu koje je namijenjeno za stanovanje. Ako plan o građenju nije još donesen, projekt gradnje je dopustiv ako je sukladan karakteru područja u cjelini, primjerice, ako je u skladu s već postojećim zgradama (čl. 34. BauGB). Građenje izvan područja postojećih građevina, osim tzv. privilegiranih projekata za poljoprivredu ili za javne svrhe, dopušteno je samo ako ne šteti javnom interesu, a pogotovo ne smije biti štetno za krajolik i okoliš (čl. 35. BauGB). Detalji o toj tematici određeni su sudskom praksom.

Građevinska dozvola (Baugenehmigung) je pretpostavka da bi se moglo pristupiti građenju nove ili izmjeni postojeće građevine. Ona osigurava da su ispunjeni zahtjevi za planiranje i građenje postavljeni u zakonu. Pri ocjeni zahtjeva osobe koja namjerava graditi (Bauherr) nadležno tijelo će ispitati je li projekt u

84 Ibid., str. 111. Za detaljniji opis v. čl. 5. Zakona o građenju (Baugesetzbuch - BauGB, zakon od 1960., u verziji objavljenoj 2004. (BGBl. I S. 2414), zadnja izmjena od 2014. (BGB1. I S. 1748).

85 Reimann, Zekoll, Introduction to German Law, 2005., str. 111.

86 Schenke, Wolf-Rüdiger, Verwaltungsprozessrecht, 14. Auflage, C. F. Müller, 2014., str. 306. 
skladu s propisima i uredbama te planom o građenju (čl. 30. BauGB). Ako projekt udovoljava svim postavljenim zahtjevima, graditelju će biti izdana građevinska dozvola, odnosno on tada ima utuživo pravo prema članku 14. GG-a, tj. pravo na građenje postaje sastavni element njegova stvarnog, odnosno vlasničkog prava.

Ako je građevinska dozvola izdana nezakonito, odnosno ako projekt ne odgovara propisima, susjedi na koje takva dozvola ima učinke mogu tužiti graditelja. Oni u tom slučaju moraju dokazati ne samo da je došlo do povrede prava općenito, nego, u najmanju ruku, da je dozvola povrijedila odredbu koja štiti njihove interese (Schutznormtheorie). ${ }^{87}$

\subsubsection{Ocjena ustavnosti lokalnih općenormativnih akata}

Do 2010. ocjenu ustavnosti drugih propisa pod koje su u većini slučajeva bili podvedeni opći akti, provodio je USUD. Dakle, postojalo je tijelo koje je nadziralo njihovu ustavnost sukladno Ustavnom zakonu o Ustavnom sudu. Uređenjem instituta objektivnog upravnog spora po kriteriju vrste akta, ojačalo je upravno sudstvo. Njemu je kroz VUS, povjerena važna zadaća očuvanja objektivne zakonitosti. Međutim, pri tom uređenju, došlo je do više pogrešaka pa je moguće zaključiti da svrha objektivnog upravnog spora koja se sastoji u očuvanju objektivne zakonitosti, a podredno i subjektivnih prava građana, nije ispunjena.

Nepostojanje zakonskih odredbi o ocjeni ustavnosti općih akata, ${ }^{88}$ stavlja na suce VUS-a koji sjede u Vijeću za ocjenu zakonitosti odgovornost koja se sastoji u tome da primjećuju neustavnost općih akata, a ne smiju to istaknuti jer se norma koja određuje njihovo postupanje u ocjeni zakonitosti općih akata ne odnosi na ocjenu njihove ustavnosti. Budući da je takvo stanje neodrživo za moderni pravni poredak, autori pronalaze uglavnom dva rješenja ${ }^{89}$ Prvo, u kojem bi se ocjena ustavnosti, uz ocjenu zakonitosti, povjerila VUS-u. Koliko je to izgledno s obzirom na to da USUD to nije izrijekom dosad rekao, niti je predviđeno nekom pravnom normom, može nam odgovoriti jedino USUD ili zakonodavac. Prednosti takvog rješenja su da je cjelokupna kontrola, dakle i ustavnosti i zakonitosti u rukama jednog tijela. ${ }^{90}$ Tako bi građani sa sigurnošću mogli znati kojem tijelu mogu podnijeti zahtjev za ocjenu zakonitosti i ustavnosti općeg akta. Međutim, nedostatak je taj da VUS, postupajući sukladno ZUS-u, mora zatražiti od pojedinca pojedinačnu odluku. Ako

87 Reimann, Zekoll, Introduction to German Law, 2005., str. 111. - 112.

88 O kontroli ustavnosti općih akata govori Ljubić, međutim, ne pravi razliku između pojmova opći akt i drugi propis, tako da se njegov rad zapravo odnosi na kontrolu propisa pred USUDom. V. u: Ljubić, Dubravko, Ustavnosudska kontrola propisa - rješenje broj: U-I-4175/2013$P P$, Hrvatska pravna revija, 14 (2014) 1; str. 8. - 9.

89 O dva moguća rješenja v. i: Antić, Teodor, Razgraničenje nadležnosti za ocjenu ustavnosti $i$ zakonitosti općih akata lokalne samouprave, Zbornik Pravnog fakulteta u Splitu, 50 (2013) 3; str. 566.

90 Takvo je i Krbekovo stajalište jer je ,najdosljednije i najpraktičnije da direktnu sudsku kontrolu, ..., vrši ono isto ustavno sudište koje vrši i tu kontrolu u pogledu ustavnosti zakona " (Krbek, Sudska kontrola naredbe, 1939., str. 191.). 
pojedinačne odluke nema, bilo iz razloga jer ju stranka odbije podnijeti ili jer se ona uopće ne donosi u konkretnoj stvari, VUS će odbaciti potencijalno neustavan akt. Svrha objektivne zakonitosti ostaje neispunjena.

Drugo je moguće rješenje da USUD prihvati ocjenjivati ustavnost općih akata. Međutim, time bi došlo do disperzije nadležnosti za kontrolu općih akata. Koliko god je rješenje da USUD rješava o ustavnosti općih akata teoretski gledano dobro iz više razloga, primjerice zbog širine znanja ustavnih sudaca i dugotrajnog iskustva u odlučivanju u toj materiji, toliko je i loše jer stvara pravnu nesigurnost. Osim toga, da je USUD namjeravao biti nadležan za ocjenjivanje ustavnosti općih akata, to bi u dvije godine rada VUS-a sasvim sigurno istaknuo. To se nije dogodilo, ali USUD je barem djelomično pokušao riješiti problem u Rješenju U-II-5157/2005 od 5. ožujka 2012. Može se uočiti da su podnositelji zahtjeva za ocjenu zakonitosti općih akata, već sad zbunjeni jer regulacija koja postoji danas nije dorađena. Ako bi se na to dodao sustav u kojem bi podnositelj koji je laik morao znati koje je tijelo nadležno za apstraktnu kontrolu zakonitosti, a koje za apstraktnu kontrolu ustavnosti, a da se pritom osporava isti akt, uvelo bi se još nepotrebnih komplikacija u već zamršeni postojeći sustav.

Unatoč nepostojanju posebnog tijela koje bi kontroliralo zakonitost općenormativnih akata lokalnih jedinica, Slovenija je zadržala sustav sličan onome kakav je Hrvatska imala do stupanja na snagu ZUS-a te time izbjegla pravnu prazninu vezano uz kontrolu ustavnosti akata jedinica lokalne i područne (regionalne) samouprave. Akti lokalnih jedinica uređeni su u osmom dijelu Zakona o lokalni samoupravi, a dijele se na opće i pojedinačne. ${ }^{91}$ Općina (občina) odlučuje o upravnim stvarima iz vlastite nadležnosti, kao i u upravnim stvarima iz prenesenoga državnog djelokruga. Opći akti koje donosi lokalno predstavničko tijelo (občinski svet) regulirani su Zakonom o lokalnoj samoupravi u VIII. glavi. ${ }^{92}$ Izrijekom je kao opći akt naveden statut lokalne jedinice (občina). Ostali akti se ne navode, međutim, zanimljivo je vidjeti da slovenski zakonodavac ne čini razliku između propisa i općih akata, barem ne u materijalnom smislu. Tako je u članku 66. stavku 1. Zakona o lokalni samoupravi propisano:

„Statut in drugi predpisi občine morajo biti objavljeni, veljati pa začnejo petnajsti dan po objavi, če ni v njih drugače določeno. "

U prijevodu, riječ je o reguliranju objave statuta i drugih propisa lokalne jedinice. ${ }^{93}$ Ovo nerazlikovanje propisa i općih akata razumljivo je zbog tijela koje provodi kontrolu nad njima. U X. poglavlju koje nosi naziv „,Nadzor državnih

91 Zakon o lokalni samoupravi, Uradni list Republike Slovenije br. 94/2007 - službeni pročišćeni tekst.

92 Zakon o lokalni samoupravi, UL 94/2007 - pročišćeni tekst, 76/2008, 79/2009, 51/2010.

93 Haček i Grabner navode da je teško raspravljati o određenom sadržaju nekog općeg akata jer svaka općina ima mogućnost autonomno urediti određena pitanja (Haček, Miro, Grabner, Anja, Local Sub-Decentralisation and Sub-Municipal Division in Slovenia, Hrvatska komparativna i javna uprava 13 (2013) 1; 2013., str. 220.). 
organov "u članku 88.a propisano je da kontrolu zakonitosti pojedinačnih i općih akata općina koji su doneseni u njihovom djelokrugu provode ministarstva, svako iz svoje nadležnosti. Osim ministarstava, za kontrolu su zaduženi župan i Vlada. ${ }^{94}$ Riječ je o kontroli koja prethodi kontroli sudova, u konkretnom slučaju, sudskoj kontroli upravnog i ustavnog suda.

U pogledu općih akata, kontrolno tijelo koje provjerava i ustavnost i zakonitost općih akata nije, kao što je slučaj u Hrvatskoj i Njemačkoj, upravni sud, nego je to isključivo USUD. Odredbom iz članka 88.a stavka 4. propisano je:

„Če organ občine ne uskladi svojega splošnega akta z ustavo ali zakonom, mora ministrstvo predlagati vladi, da zahteva začetek postopka pred ustavnim sodiščem za oceno skladnosti splošnega akta občine z ustavo in zakonom. "95

Upravni sud nadležan je samo za ocjenu zakonitosti pojedinačnih akata koji su doneseni u upravnom postupku (čl. 69. Zakona o lokalnoj samoupravi). ${ }^{96}$

\subsubsection{Izvanredno preispitivanje zakonitosti pravomoćne presude VUS-a o ocjeni zakonitosti općih akata jedinica lokalne i područne (regionalne) samouprave}

Prema trenutnom uređenju objektivnog upravnog spora VUS je zadnja instanca u provođenju redovite kontrole nad općim aktima jedinica lokalne i područne (regionalne) samouprave. Podnositelj zahtjeva za ocjenu zakonitosti općeg akta često je onemogućen da ishodi odluku VUS-a o nezakonitosti zbog niza postupovnih prepreka. Do izmjena ZUS-a 2014. ocjena zakonitosti općih akata bila je moguća samo ako je zahtjev podnijela stranka kojoj je bila dostavljena pojedinačna odluka javnopravnog tijela kojom je bilo povrijeđeno neko njeno pravo ili pravni interes. Takvo je uređenje dosta strogo samo po sebi, a dodatno ga je postrožio VUS svojom praksom prema kojoj VUS nije prihvaćao one zahtjeve koji su mu pristigli s prekoračenjem roka od 30 dana iako su uredno i u roku bili predani nekom drugom tijelu sa svrhom ocjene zakonitosti općeg akta. Nadalje, VUS nije uzimao u razmatranje one akte koje bi donijelo nenadležno tijelo te su na snazi ostajali akti koji su očito nezakoniti, ali zbog nedostatka formalnih pretpostavki nisu se u praksi VUS-a smatrali općim aktima te zahtjevi za ocjenu njihove zakonitosti bili odbačeni. U navedenim situacijama, podnositeljima se zatvara put pravne zaštite. $\mathrm{O}$ navedenim rješenjima već je bilo riječi, a na ovom ćemo se mjestu zadržati samo na

94 Dubajić, Daria, Lokalna samouprava u Sloveniji, Hrvatska javna uprava, 10 (2010) 2; str. 480.

95 U prijevodu: „Ako tijelo općine ne uskladi svoj opći akt s ustavom ili zakonom, ministarstvo mora predložiti vladi, da zahtijeva početak postupka za ocjenu suglasnosti općeg akta općine s ustavnom i zakonom pred ustavnim sudom."

96 Kontrola akta koje provodi ministarstvo te postupak upućivanja ustavnom sudu za ocjenu ustavnosti i zakonitosti regulirani su i odredbama u čl. 64., 65. i 66., Zakona o državni upravi, UL 113/2005, 48/2009, 21/2012, 47/2013, 12/2014, 90/2014. Isti zakon regulira provođenje kontrole nad aktima osoba s javnim ovlastima. 
izvanrednom pravnom sredstvu - zahtjevu za izvanredno preispitivanje zakonitosti pravomoćne presude VUS-a o ocjeni zakonitosti općih akata jedinica lokalne i područne (regionalne) samouprave.

Odredbama članka 78. ZUS-a uređen je institut izvanrednog preispitivanja zakonitosti pravomoćne presude. Stranke mogu predložiti Državnom odvjetništvu Republike Hrvatske da podnese zahtjev za preispitivanje pravomoćne presude ili rješenja upravnog ili VUS-a. Zahtjev može podnijeti Državno odvjetništvo po službenoj dužnosti ili u roku od šest mjeseci od dana dostave pravomoćne sudske presude strankama. O zahtjevu odlučuje Vrhovni sud Republike Hrvatske u sastavu od pet sudaca. Ako zahtjev usvoji, može ukinuti presudu i vratiti predmet na ponovo rješavanje ili može preinačiti presudu. Sve navedeno vrijedi kada je riječ o presudama upravnih, odnosno Visokih upravnih sudova kod ispitivanja zakonitosti pojedinačnih akata. Međutim, pred Vrhovnim se sudom pojavilo i pitanje odlučivanja o zakonitosti općeg akta jedinice lokalne i područne (regionalne) samouprave te je Vrhovni sud donio rješenje o odbacivanju zahtjeva kao nedopuštenog. U rješenju U-zpz 10/14-4 od 4. veljače 2015. navedeno je sljedeće: „Prema shvaćanju ovoga suda zahtjev za izvanredno preispitivanje zakonitosti pravomoćne presude nije dopušten u postupku radi ocjene zakonitosti općeg akta“.

Navedeno je obrazloženo trima argumentima. Prema prvom, ovaj se izvanredni pravni lijek ne može primijeniti jer je propisan u glavi trećoj, a ocjena zakonitosti u glavi šestoj, te zbog toga jer bi se taj pravni lijek trebao primjenjivati samo $\mathrm{u}$ postupku u kojem se radi o nekom pojedinačnom pravu stranke o kojem se odlučuje o upravnom postupku. Ni u jednom zakonu ono što je napisano prije ne isključuje ono što je napisano poslije, a ni obrnuto. Navedeno bi tumačenje predstavljalo suprotnost cjelovitom ili holističkom i teleološkom tumačenju nekog zakona. Ovakvo gramatičko tumačenje važnog izvanrednog pravnog lijeka u kojem je čak izrijekom propisano da se može podnijeti protiv pravomoćne presude upravnih i VUS-a, pokušava isključiti primjenjivost izvanrednog pravnog lijeka izričito propisanog ZUS-om sa svrhom osiguranja zakonitosti u pogledu ocjene zakonitosti općih akata jedinica lokalne i područne (regionalne) samouprave. ${ }^{97}$ Nadalje, pojedinačni se akti donose na temelju općenormativnih. Dakle, pojedinačni akti moraju biti utemeljeni u nekoj višoj pravnoj normi. Riječ je o pravnoj vezanosti kao jednoj od bitnih karakteristika upravnog akta, ${ }^{98}$ ukratko, riječ je o poštivanju načela zakonitosti. Neki pojedinačni akt ne može biti zakonit ako je donesen temeljem nezakonitog općeg akta te je potrebno ispitati i zakonitost temelja za pojedinačni akt koji se nalazi u općenormativnom aktu. ${ }^{99}$

97 Staničić navodi da iako ZUS izrijekom ne propisuje da se to izvanredno pravno sredstvo može koristiti protiv tih rješenja i/ili presuda, ta je mogućnost otvorena Zakonom o sudovima u čl. 20. st. 3. (Staničić, Frane, Mogućnost primjene izvanrednog preispitivanja zakonitosti pravomoćne presude protiv odluka Visokog upravnog suda, Informator, br. 6399 od 4. siječnja 2016., str. 15.)

98 V. Borković, Upravno pravo, 2002., str. 362.

99 Za dodatne argumente koji govore o prilog primjeni izvanrednog pravnog lijeka za izvanredno preispitivanje zakonitosti pravomoćne presude VUS-a u slučaju ocjene zakonitosti općih 
Drugi argument Vrhovnog suda je u tome da se stranka može zaštititi na način da podnese zahtjev nadležnom javnopravnom tijelu za izmjenu pojedinačne odluke javnopravnog tijela kojom je povrijeđeno neko pravo ili pravni interes odgovarajućom primjenom odredaba o obnovi upravnog postupka u roku od tri mjeseca od dana objave presude u narodnim novinama. S ovim se argumentom ne bismo mogli složiti. Javnopravnom tijelu za izmjenu pojedinačne odluke javit će se one stranke koje su uspjele u postupku pred VUS-om, odnosno ako je nezakoniti akt ukinut pa imaju temelj za traženje izmjene odluke koja je donesena temeljem nezakonitog. Vrhovnom sudu će se javiti pretežno stranke koje žele ostvariti svoja prava koja im vrijeđa nezakoniti akt, dakle one koje nisu uspjele u postupku pred VUS-om te je njihov zahtjev odbačen ili odbijen. Nadalje, Vrhovni sud nije uzeo u obzir situaciju u kojoj je VUS nezakonito postupio i ukinuo zakoniti opći akt. Stoga obraćanje javnopravnom tijelu ne predstavlja alternativu za preispitivanje zakonitosti pravomoćne presude VUS-a, a Vrhovni sud bi trebao predstavljati kontrolni mehanizam nad pravomoćnim presudama VUS-a te postupiti po zahtjevu Državnog odvjetništva ako ono podnese zahtjev smatrajući da je VUS postupio nezakonito.

Treći argument kojim Vrhovni sud pokušava otkloniti svoju nadležnost je $u$ tome što $u$ dijelu u kojem je regulirana ocjena zakonitosti općih akata nije spomenuto to da se stranka može obratiti Vrhovnom sudu, te se ponovo govori o postavljanju zahtjeva javnopravnom tijelu prema odredbama o ponavljanju postupku. Odnosno, ovaj treći argument spaja prva dva u argumente koji ne stoje zasebno, a ni zajedno.

Za istaknuti je da argumenti i navedno tumačenje Vrhovnog suda Republike Hrvatske nisu prihvatljivi iz više razloga. Kao prvo, tumačenju ZUS-a nije pristupljeno sistematično i na holistički ili sveobuhvatni način. Nedopustivo je cjepkanje jednog cjelovitog zakona na sastavne dijelove. Logikom Vrhovnog suda Republike Hrvatske, VUS uopće ne bi trebao primjenjivati ZUS jer u prvom članku ZUS-a nije propisano da je predmet ovog zakona postupanje VUS-a nego se spominju samo upravni sudovi. ${ }^{100}$ To što je kasnije izrijekom propisano da je predmet upravnog spora i ocjena zakonitosti općih akata, bilo bi manje važno jer se ne nalazi u istom članku gdje je propisan predmet zakona.

Drugo, valja uzeti u obzir da je VUS prva i zadnja instanca u redovnom postupku ocjene zakonitosti općih akata što znači da je riječ o jednostupanjskom postupku. Ustavna tužba se za sad ne može podnijeti, a izvanrednog pravnog lijeka, ako se isključi zahtjev Vrhovnom sudu Republike Hrvatske, nema.

akata v. u: Staničić, Mogućnost primjene izvanrednog preispitivanja zakonitosti pravomoćne presude protiv odluka Visokog upravnog suda, Informator, br. 6399 od 4. siječnja 2016., str. 13. -15 .

100 Članak 1. ZUS-a glasi: „Ovim se Zakonom uređuju nadležnost, sastav suda i pravila postupka na temelju kojih upravni sudovi odlučuju o zakonitosti odluka javnopravnih tijela o pravima, obvezama i pravnim interesima fizičkih $i$ pravnih osoba $i$ drugih stranaka te o zakonitosti postupanja javnopravnih tijela iz područja upravnog prava (u daljnjem tekstu: upravni spor). “ 
Treće, nikako se zahtjev javnopravnom tijelu ne može poistovjetiti s nekim sudskim sredstvom. Dojam je da Vrhovni sud prilikom donošenja citiranog rješenja ni $\mathrm{u}$ jednom trenu nije uzeo u obzir da je svrha objektivnog upravnog spora reguliranog u člancima 83. - 88. ZUS-a u ostvarenju objektivne zakonitosti. Dakle, ta važna svrha objektivnog upravnog spora koja se sastoji u očuvanju objektivne zakonitosti, odnosno u sprečavanju toga da temeljem jednog nezakonitog općenormativnog akta bude donesen neodređen broj nezakonitih pojedinačnih akata uopće nije bila uzimana u obzir, što je pogrešno i kosi se sa svrhom ZUS-a, ali i s ustavnom vrednotom vladavine prava.

\section{ZAKLJUČAK}

Akte jedinica lokalne i područne (regionalne) samouprave u Republici Hrvatskoj kontroliraju upravni sudovi, VUS i USUD. Podjela je izvršena nakon reforme upravnog sudovanja koja je rezultirala donošenjem novoga ZUS-a kojim je uvedeno dvostupanjsko upravno sudovanje. Budući da je podjela općenormativnih akata uređena na način da postoje opći akti i drugi propisi, njih nadziru različita tijela.

Kontrola statuta lokalnih jedinica u rukama je USUD-a, dok ostale opće akte lokalnih jedinica kontrolira VUS. Odredba članka 3. stavka 2. ZUS-a prema kojoj je VUS nadležan za kontrolu općih akata tijela jedinica lokalne i područne (regionalne) samouprave, a ne samo općih akata predstavničkih tijela, ostavlja VUS-u široku mogućnost za tumačenje navedene odredbe prema kojoj bi se osim općih akata koje donese predstavničko tijelo JLRS mogli ocjenjivati i oni akti koji su apstraktni i generalni, a ne donosi ih isključivo predstavničko tijelo.

Nadalje, mislimo da je obveza sudaca VUS-a da prilikom uočene nezakonitosti općeg akta iz razloga nenadležnosti, dakle kada opći akt donose nenadležno tijelo, upozoriti na takvu nezakonitost te nezakoniti općnormativni akt sankcionirati stavljanjem izvan snage. Navedeno rješenje poznaje francusko pravo, ali i naš ZUS u dijelu u kojem je propisana kontrola nad pojedinačnim aktima. Uz to, posebni zakoni nisu usklađeni sa ZUS-om, a kao primjer se može navesti ZPU koji i dalje propisuje da su prostorni planovi po svojoj pravnoj prirodi propisi. Budući da VUS ne kontrolira propise nego opće akte, nužno je navedenu odredbu mijenjati sukladno prijedlogu iznesenom u ovom radu. Veliki je nedostatak u zakonskoj regulativi nepostojanje kontrole nad ustavnošću općih akata jedinica lokalne i područne (regionalne) samouprave. Uz to, nedostatak se može pronaći i u stajalištu Vrhovnog suda Republike Hrvatske prema kojem on nije nadležan za postupanje po izvanrednom pravnom lijeku - zahtjevu za izvanredno preispitivanje zakonitosti pravomoćne presude VUS-a ako je VUS odlučivao o ocjeni zakonitosti općeg akta. Komparativna rješenja većinom su sustavnija i sređenija od trenutnog hrvatskog uređenja, iako nikako ne smijemo zanemariti činjenicu da je sama reforma upravnog sudovanja pružila barem temelje za bolje i uređenije djelovanje sudova u kontroli akata jedinica lokalne i područne (regionalne) samouprave nego je to bio slučaj do 2010. i ranije. 


\section{Summary}

\section{ADMINISTRATIVE JUDICIAL CONTROL AND CONSTITUTIONAL CONTROL OF LEGALITY OF THE LOCAL SELF-GOVERNMENT ACTS}

The administrative courts' reform in Croatia has caused changes in special legislation. Important consequence of the reform is a different judicial control over local government acts. Under the current regulation, the Constitutional Court of the Republic of Croatia is competent for the control of constitutionality and legality of the local statutes, and High Administrative Court is the competent body for the review of the legality of general acts of local self-government. The paper also analyzes comparative solutions related to the issue of judicial review of general acts of local and regional government, especially French, German and Slovenian regulation.

Key words: judicial control, general acts of local self-government, administrative reform.

\section{Zusammenfassung}

\section{VERWALTUNGSGERICHTLICHE UND VERFASSUNGSKONTROLLE DER RECHTMÄSSIGKEIT DER KOMMUNALEN SELBSTVERWALTUNGSGESETZE}

Die Reform der Verwaltungsgerichtsbarkeit hat durch die neue Regulierung der Verwaltungsgerichtsbarkeit und Verwaltungsgerichtorganisation die Änderungen auch in besonderer Gesetzgebung bewirkt. So traten die Änderungen des Gesetzes über die lokale und regionale Selbstverwaltung ein. Für diese Arbeit sind die Änderungen im Blick zur Gerichtskontrolle über die Lokalakten wichtig, die vor der Reform das Verwaltungsgericht der Republik Kroatien und das Verfassungsgericht betrieben haben. Das Verfassungsgericht hat laut der aktuellen Einrichtung die Zuständigkeit für die Verfassungs- und Gesetzlichkeitskontrolle nur über die Statute der Lokaleinheiten behalten. Verwaltungsgerichte in Zagreb, Rijeka, Osijek und Split kontrollieren die einzelnen Akte im ersten Grad und Klageprozesse auch der Hohe Verwaltungsgerichtshof. Für die Kontrolle der Grundakte, welche die Lokaleinheiten erlassen ist der Hohe Verwaltungsgerichtshof der Republik Kroatien zuständig. In dieser Arbeit werden auch die komparativen Lösungen, die mit der Problematik der Gerichtskontrolle von Lokalakten verbunden sind, analysiert und zwar die französische, deutsche und slowenische Anordnung.

Schlüsselwörter: Gerichtskontrolle, Lokalakte, Verwaltungsreform. 


\section{Riassunto}

\section{IL CONTROLLO GIUSAMMINISTRATIVO E GIUSCOSTITUZIONALE DI LEGALITÀ DEGLI ATTI DEGLI ENTI LOCALI E REGIONALI}

La riforma della giustizia amministrativa ha comportato mediante la nuova disciplina del contenzioso amministrativo e dell'organizzazione dei tribunali amministrativi modifiche anche nella legislazione speciale. In tale modo sono intervenute le modifiche della legge sull'amministrazione locale e regionale. Precisamente, per quanto interessa il presente lavoro, rilevano le modifiche che riguardano il controllo giudiziario sugli atti locali, il quale prima della riforma veniva effettuato dal Tribunale amministrativo della Repubblica di Croazia e dalla Corte costituzionale. La Corte costituzionale in base all'attuale organizzazione ha mantenuto la competenza per il vaglio della legittimità costituzionale e della legalità soltanto nei confronti degli statuti degli enti locali; mentre, i singoli atti in prima istanza vengono controllati dai tribunali amministrativi di Zagreb, Rijeka, Osijek e Split, e nel procedimento di impugnazione anche dall'Alta corte amministrativa. Per il controllo degli atti generali che emanano gli enti locali è competente l'Alta corte amministrativa della Repubblica di Croazia. Nel lavoro vengono altresì analizzate le soluzioni di diritto comparato connesse alla questione del controllo giudiziario degli atti locali, intendendo all'uopo i sistemi francese, tedesco e sloveno.

Parole chiave: controllo giudiziario, atti locali, riforma amministrativa. 